Dinamika Kesehatan Jurnal Kebidanan dan Keperawatan Vol 10 No. 1 Juli 2019 ( ISSN: 2086-3454 EISSN: 2549-4058)

url: http://ojs.dinamikakesehatan.unism.ac.id DOI : https://doi.org/10.33859/dksm.v10i1.462

Perbedaan Gambaran Ekg Pada Pasien Hipertensi Dengan Lama Riwayat Menderita <5 Tahun Dan $\geq 5$ Tahun

Di Poli Penyakit Dalam Rumah Sakit H. Damanhuri Barabai

\title{
Perbedaan Gambaran Ekg Pada Pasien Hipertensi Dengan Lama Riwayat Menderita < 5 Tahun Dan $\geq 5$ Tahun Di Poli Penyakit Dalam Rumah Sakit H. Damanhuri Barabai
}

\author{
Taufikurrahman $^{1}$, Abdurahman Wahid ${ }^{1}$, Ichsan Rizany ${ }^{1}$ \\ ${ }^{1}$ Program Studi Ilmu Keperawatan, Fakultas Kedokteran, Universitas Lambung Mangkurat, \\ Jl. A. Yani KM. 36 Banjarbaru, 70714 \\ Email korespondensi: trapeziuzz@gmail.com
}

DOI: https://doi.org/10.33859/dksm.v10i1.462

\begin{abstract}
Abstrak
Latar Belakang: Deteksi dini risiko komplikasi kardiovaskuler pada penderita hipertensi salah satunya dengan mengetahui profil Elektrokardiogram (EKG) penderita hipertensi. EKG penderita hipertensi yang memiliki lama menderita akan berisiko tinggi terhadap kelainan jantung.

Tujuan: penelitian ini untuk mengetahui perbedaan gambaran EKG pada pasien hipertensi dengan lama riwayat menderita $<5$ tahun dan $\geq 5$ tahun di Poli Penyakit Dalam Rumah Sakit H. Damanhuri Barabai.

Metode: Penelitian deskriptif komparatif dengan desain cross sectional dengan jumlah sampel 60 orang terbagi dalam dua kelompok menggunakan teknik accidental sampling.

Hasil: penelitian menunjukkan gambaran EKG pada pasien hipertensi dengan lama riwayat menderita $<5$ tahun yang normal sebanyak 22 orang $(73,3 \%)$ dan lama riwayat menderita $\geq 5$ tahun tidak normal sebanyak 21 orang $(70 \%)$. Hasil analisis menunjukkan terdapat perbedaan gambaran EKG pada pasien hipertensi dengan lama riwayat menderita $<5$ tahun dan $\geq 5$ tahun.

Semakin lama menderita hipertensi, dapat berpotensi gambaran EKG mengarah pada gambaran hipertrofi ventrikel kiri, yang berakibat pada prevalensi gagal jantung.

Kata-kata kunci: elektrokardiogram, hipertensi, lama riwayat.
\end{abstract}

Differences in Ecg Images in Hypertensive Patients with Long History of Suffering $<5$ Years And $\geq 5$ Years On Poli Penyakit Dalam Rumah Sakit H. Damanhuri Barabai

\begin{abstract}
Background: Early detection of the risk of cardiovascular complications in hypertensive patients is one of them by knowing the electrocardiogram (ECG) profile of hypertensive patients. Patients with ECG hypertension who have long suffered will be at high risk of experiencing heart abnormalities.

Objective: to investigate differences in ECG description in patients and hypertensive patients with a long history of suffering $<5$ years and $\geq 5$ years at the Internal Medicine Clinic of H. Damanhuri Barabai Hospital.

Method: Comparative descriptive study with cross sectional design with a sample of 60 people divided into two groups using accidental sampling techniques.

Results: the study showed a picture of ECG in hypertensive patients with a normal history of suffering from $<5$ years of age 22 people (73.3\%) and a history of suffering $\geq 5$ years of abnormalities of 21 people (70\%). The analysis showed that there were differences in ECG features in hypertensive patients with a history of $<5$ years and $>5$ years.

The longer you suffer from hypertension, this has the potential to cause an ECG picture that leads to a picture of left ventricular hypertrophy, which results in the prevalence of heart failure.
\end{abstract}

Keywords: electrocardiogram, hypertension, length of history. 
Dinamika Kesehatan Jurnal Kebidanan dan Keperawatan Vol 10 No. 1 Juli 2019 ( ISSN: 2086-3454 EISSN: 2549-4058) url: http://ojs.dinamikakesehatan.unism.ac.id DOI : https://doi.org/10.33859/dksm.v10i1.462

Perbedaan Gambaran Ekg Pada Pasien Hipertensi Dengan Lama Riwayat Menderita <5 Tahun Dan $\geq 5$ Tahun Di Poli Penyakit Dalam Rumah Sakit H. Damanhuri Barabai

PENDA HULUAN

Hipertensi adalah penyakit yang ditandai dengan adanya tekanan darah yang mengalami peningkatan di atas normal standar tekanan darah, dimana nilai tekanan darah sistolik $\geq 140 \mathrm{mmHg}$, sementara itu pada tekanan darah diastolik $\geq 90 \mathrm{mmHg}$, berdasarkan hasil dari dua kali pemeriksaan tekanan darah dengan rentang waktu selama lima menit pada kondisi istirahat dan tenang (WHO, 2013).

Hipertensi menjadi salah satu faktor yang menyebabkan timbulnya penyakit tidak menular (Non Communicable Disease/NCD) dan berdampak pada kerusakan organ ginjal, penyakit jantung koroner, dan penyakit pada organ otak seperti stroke (Kemenkes, 2015). Data American

\section{Heart Association (AHA) menyebutkan} bahwa insiden hipertensi sudah mencapai 74,5 juta jiwa terhadap penduduk Amerika yang berusia $>20$ tahun, tetapi sekitar 90 sampai 95\% kasus tidak diketahui pemicunya (Kemenkes, 2014).
Gambaran pada tahun 2013 dengan

memakai unit analisis individu didapatkan sebesar $25,8 \%$ penderita hipertensi secara nasional terhadap penduduk Indonesia. Jumlah penduduk Indonesia pada saat ini sebanyak 252.124.458 jiwa, maka didapatkan penderita hipertensi sebanyak 65.048 .110 jiwa. Ditemukan persentase tertinggi ditemukan 30,9\% di Provinsi Bangka Belitung. Sementara secara absolut di Kalimantan Selatan penderita hipertensi menempati urutan kedua di Indonesia berdasarkan hasil Riskesdas (2013) sebesar $30,8 \% x 3.913 .908 \quad$ jiwa $=1.205 .483$ jiwa. Prevalensi hipertensi di Kalimantan Selatan dari 13 kabupaten/kota didapatkan Kabupaten Hulu Sungai Tengah menduduki urutan pertama persentasi yang terbanyak penderita hipertensi dengan 38,7\% (Riskesdes, 2013).

Komplikasi yang dialami oleh penderita hipertensi terjadi akibat adanya tekanan darah yang mengalami peningkatan dan berlangsung secara berkepanjangan, sehingga beakibat pada perubahan dinding pembuluh darah dan jantung, atau akibat terjadinya 
Dinamika Kesehatan Jurnal Kebidanan dan Keperawatan Vol 10 No. 1 Juli 2019 ( ISSN: 2086-3454 EISSN: 2549-4058)

url: http://ojs.dinamikakesehatan.unism.ac.id DOI : https://doi.org/10.33859/dksm.v10i1.462

Perbedaan Gambaran Ekg Pada Pasien Hipertensi Dengan Lama Riwayat Menderita <5 Tahun Dan $\geq 5$ Tahun

Di Poli Penyakit Dalam Rumah Sakit H. Damanhuri Barabai

proses aterosklerosis yang diperparah dengan

terjadinya hipertensi (Sawicka, 2011).

Deteksi dini terhadap kejadian

komplikasi hipertensi dan risiko tinggi

terjadinya penyakit kardiovaskuler berperan

sangat penting untuk melaksanakan

pengontrolan komplikasi hipertensi terutama

terjadinya gagal jantung. Prevalensi penyakit

gagal jantung pada hipertensi juga dapat

diperparah oleh lamanya riwayat penyakit

pada penderita. Peningkatan tekanan darah

dan berlangsung dalam waktu yang lama

(persisten)

seperti

lebih

dari lima tahun memiliki risiko

lebih tinggi menimbulkan kerusakan pada

ginjal dan kerusakan jantung (Kemenkes.).

Metode yang bisa diIakukan untuk melakukan

deteksi dini risiko komplikasi kardiovaskuler

pada penderita hipertensi salah satunya yakni

dengan mengetahui profil Elektrokardiogram

(EKG) penderita hipertensi.

Penelitian Soraya dkk (2016)

melaporkan bahwa pada penderita hipertensi

yang mengetahui kondisi hipertensinya

selama 10 tahun cenderung mengalami hipertrofi ventrikel kiri (HVK). HVK

merupakan gambaran klinis yang paling sering timbul pada jantung dampat dari terjadinya hipertensi dan bisa

dideteksi melalui perekaman jantung dengan menggunakan elektrokardiografi

(EKG). Secara umum profil EKG penderita hipertensi dapat terdiri dari berbagai grafik mulai dari gambaran EKG normal, atrial fibrilasi, aritmia ataupun grafik-grafik lain, seIain hipertrofi ventrikel kiri (Soraya, 2016).

Berdasarkan laporan penyakit akhir tahun Rumah Sakit H. Damanhuri, hipertensi menduduki urutan pertama penyakit rawat jalan terbanyak pada tahun 2016 sebanyak 1656 pasien dan pada tahun 2017, hipertensi menduduki urutan ke empat penyakit rawat jalan sebanyak 1681 pasien. Hasil dari studi pendahuluan yang diIakukan oIeh peneIiti pada 10 pasien yang menderita hipertensi pada tanggal 3 Mei 2018 di Poli Penyakit Dalam Rumah Sakit Damanhuri didapati sekitar $10 \%$ dari pasien didiagnosis dengan hipertrofi ventrikel kiri, meningkatnya angka kejadian hipertensi yang tidak terkontrol 
Dinamika Kesehatan Jurnal Kebidanan dan Keperawatan Vol 10 No. 1 Juli 2019 ( ISSN: 2086-3454 EISSN: 2549-4058)

url: http://ojs.dinamikakesehatan.unism.ac.id DOI : https://doi.org/10.33859/dksm.v10i1.462

Perbedaan Gambaran Ekg Pada Pasien Hipertensi Dengan Lama Riwayat Menderita <5 Tahun Dan $\geq 5$ Tahun

Di Poli Penyakit Dalam Rumah Sakit H. Damanhuri Barabai

secara dini serta peran lamanya hipertensi

pada beberapa kasus ketidaknormalan

gambaran EKG seperti gambaran grafik

hipertrofi ventrikel kiri. Tujuan penelitian ini

untuk mengetahui perbedaan gambaran EKG

pada pasien hipertensi dengan lama riwayat

menderita $<5$ tahun dan $\geq 5$ tahun di Poli Penyakit

Dalam Rumah Sakit H. Damanhuri Barabai.

\section{METODE PENELITIAN}

Penelitian menggunakan deskriptif

komparatif dengan desain cross sectional.

Populasi penelitian ini semua penderita

hipertensi di poli penyakit dalam Rumah

Sakit H. Damanhuri Barabai pada bulan Januari-Maret 2018 yakni sebanyak 412 orang. Teknik sampling penelitian ini menggunakan accidental sampling dengan sampel 60 pasien yang dibagi menjadi dua keIompok dimana 30 orang untuk kelompok responden yang lama riwayat menderita $<5$ tahun dan 30 orang untuk kelompok responden yang lama riwayat menderita $\geq 5$ tahun. Instrumennya adalah lembar karakteristik responden terdiri dari usia, jenis kelamin, pendidikan, pekerjaan pasien dan lama menderita hipertensi dan lembar observasi gambaran EKG yang dibuat sendiri oleh peneliti berlandaskan dari teori. Penelitian ini telah mendapatkan surat $\begin{array}{llll}\text { kelaikan } & \text { etik dari }\end{array}$

(Institutional Review Board) Fakultas

Kedokteran Universitas Lambung

Mangkurat dengan nomer surat sebagai $\begin{array}{lll}\text { berikut } & \text { No. } & \text { 852/KEKP-FK }\end{array}$ UNLAM/EC/VIII/2018. Penelitian ini dilaksanakan pada tanggal 27 Agustus 2018 sampai 27 Oktober 2018.

\section{HASIL DAN PEMBAHASAN}

Tabel 1. Karakteristik Responden Pada Pasien Hipertensi di Poli Penyakit $(\mathrm{n}=60)$.

\begin{tabular}{|c|c|c|c|c|}
\hline \multirow{3}{*}{$\begin{array}{c}\text { Karakteristik } \\
\text { Repsonden }\end{array}$} & \multicolumn{4}{|c|}{$\begin{array}{c}\text { Lama Riwayat Penyakit } \\
\text { Hipertensi }\end{array}$} \\
\hline & \multicolumn{2}{|c|}{$<5$ tahun } & \multicolumn{2}{|c|}{$\geq 5$ tahun } \\
\hline & $\mathrm{f}$ & $\%$ & $\mathrm{f}$ & $\%$ \\
\hline \multicolumn{5}{|l|}{ Usia } \\
\hline 18-40 tahun & 11 & 36,7 & 2 & 6,7 \\
\hline 41-60 tahun & 17 & 56,6 & 19 & 63,3 \\
\hline$>60$ tahun & 2 & 6,7 & 9 & 30 \\
\hline \multicolumn{5}{|l|}{ Jenis Kelamin } \\
\hline Laki-laki & 24 & 80 & 25 & 83,3 \\
\hline Perempuan & 6 & 20 & 5 & 16,7 \\
\hline \multicolumn{5}{|c|}{ Pendidikan Terakhir } \\
\hline Tidak sekolah & 1 & 3,3 & 6 & 20 \\
\hline $\begin{array}{l}\mathrm{SD} / \\
\text { Sederajat }\end{array}$ & 2 & 6,7 & 5 & 16,7 \\
\hline $\begin{array}{l}\text { SMP/ } \\
\text { Sederajat }\end{array}$ & 6 & 20 & 3 & 10 \\
\hline $\begin{array}{l}\text { SMA/ } \\
\text { Sederajat }\end{array}$ & 8 & 26,7 & 13 & 43,3 \\
\hline $\begin{array}{l}\text { Diploma III/ } \\
\text { Diploma IV }\end{array}$ & 6 & 20 & 0 & 0 \\
\hline Sarjana & 7 & 23,3 & 3 & 10 \\
\hline \multicolumn{5}{|l|}{ Pekerjaan } \\
\hline Tidak bekerja & 1 & 3,3 & 2 & 6,7 \\
\hline Petani/ Buruh & 0 & 0 & 4 & 13,3 \\
\hline Swasta & 9 & 30 & 11 & 36,7 \\
\hline $\begin{array}{l}\text { PNS/TNI/ } \\
\text { POLRI }\end{array}$ & 14 & 46,7 & 11 & 36,7 \\
\hline Pelajar/ & 2 & 6,7 & 0 & 0 \\
\hline
\end{tabular}


Dinamika Kesehatan Jurnal Kebidanan dan Keperawatan Vol 10 No. 1 Juli 2019 ( ISSN: 2086-3454 EISSN: 2549-4058)

url: http://ojs.dinamikakesehatan.unism.ac.id DOI : https://doi.org/10.33859/dksm.v10i1.462

Perbedaan Gambaran Ekg Pada Pasien Hipertensi Dengan Lama Riwayat Menderita <5 Tahun Dan $\geq 5$ Tahun

Di Poli Penyakit Dalam Rumah Sakit H. Damanhuri Barabai

\begin{tabular}{lcccc}
\hline Mahasiswa & & & & \\
Ibu Rumah & 4 & 13,3 & 2 & 6,7 \\
Tangga & 0 & 0 & 0 & 0 \\
lain-lain & 30 & 100 & 30 & 100 \\
\hline Total & &
\end{tabular}

Tabel 1. Memperlihatkan usia pada penderita hipertensi dengan lama riwayat menderita hipertensi $<5$ tahun yang terbanyak adalah usia 41-60 tahun sebanyak 17 orang (56,6\%). Rerata usia pasien hipertensi 45,93 tahun, median usia pasien 46,50 tahun, usia tertinggi 78 tahun, usia terendah 31 tahun dan standar deviasi 10.359 . Usia pada penderita hipertensi dengan lama riwayat menderita hipertensi $\geq 5$ tahun yang terbanyak adalah usia 41-60 tahun sebanyak 19 orang $(63,3 \%)$. Rata-rata usia responden 56,90. tahun, median usia 55,50 tahun, usia tertinggi 76 tahun, usia terendah 38 tahun dan standar deviasi 9.091.

Jenis kelamin pada penderita hipertensi dengan lama riwayat menderita hipertensi $<5$ tahun yang terbanyak adaIah Iaki-Iaki sebanyak 24 orang (80\%). Jenis kelamin pada penderita hipertensi dengan lama riwayat menderita hipertensi $\geq 5$ tahun yang terbanyak adaIah Iaki-Iaki berjumIah 25 orang $(83,3 \%)$. pendidikan terakhir pada penderita hipertensi dengan lama riwayat menderita hipertensi $<5$ tahun yang terbanyak SMA/Sederajat sebanyak 8 orang $(26,7 \%)$. Pendidikan terakhir pada penderita hipertensi dengan lama riwayat menderita hipertensi $\geq 5$ tahun berdasarkan pendidikan terakhir yang terbanyak SMA/Sederajat sebanyak 13 orang (43,3\%). pekerjaan pada penderita hipertensi dengan lama riwayat menderita hipertensi $<5$ tahun yang terbanyak PNS/TNI/POLRI sebanyak 14 orang $(46,7 \%)$. Pekerjaan pada penderita hipertensi dengan lama riwayat menderita hipertensi $\geq 5$ tahun berdasarkan pekerjaan yang terbanyak PNS/TNI/POLRI dan swasta masing-masing sebanyak 11 orang $(36,7 \%)$.

Tabel 2. Gambaran EKG Pada Pasien Hipertensi dengan Lama Riwayat Menderita <5 Tahun.

\begin{tabular}{lccc}
\hline \multicolumn{2}{c}{ Gambaran EKG } & $\mathrm{f}$ & $\%$ \\
\hline Tidak Normal & 8 & 26,7 \\
Normal & Total & 22 & 73,3 \\
\hline \multicolumn{2}{c}{} & 30 & 100 \\
\hline
\end{tabular}

Tabel 2. Gambaran EKG pada pasien hipertensi dengan lama riwayat menderita $<5$ tahun di Poli Penyakit Dalam Rumah Sakit H. Damanhuri Barabai normal sebanyak 22 orang $(73,3 \%)$ dan tidak normal sebanyak 8 orang (26\%). Pada pasien yang mengalami gambaran EKG tidak normal didapatkan 5 
Dinamika Kesehatan Jurnal Kebidanan dan Keperawatan Vol 10 No. 1 Juli 2019 ( ISSN: 2086-3454 EISSN: 2549-4058)

url: http://ojs.dinamikakesehatan.unism.ac.id DOI : https://doi.org/10.33859/dksm.v10i1.462

Perbedaan Gambaran Ekg Pada Pasien Hipertensi Dengan Lama Riwayat Menderita <5 Tahun Dan $\geq 5$ Tahun

Di Poli Penyakit Dalam Rumah Sakit H. Damanhuri Barabai

pasien $(62,5 \%)$ mengalami pembesaran ruang jantung, 1 orang mengalami ST elevasi, 1 orang mengalami ST elevasi dan AV block dan 1 orang mengalami ICRBBB. Ketidaknormalan gambaran EKG pada pasien yang menderita hipertensi dengan lama riwayat menderita $<5$ tahun dikarenakan adanya kelainan left atrial enlargemet yang dialami 5 pasien. Pasien yang mengalami left atrial enlargemet 4 orang yang dialami lakilaki. Rerata usia responden daIam peneIitian ini adalah 45,93 tahun. Faktor lain terjadinya kelainan jantung juga dipengaruhi oleh gaya hidup seseorang yang kurang baik, sehingga memunculkan adanya kelainan jantung lain. Pada penelitian ini ditemukan ada beberapa orang yang mengalami 2 kelainan jantung.

Adanya pembesaran atrium kiri pada elektrokardiografi bisa dikarenakan oIeh adanya peningkatan tekanan pada atrium kiri, penebalan pada dinding atrium kiri, gangguan konduksi atrium kiri atau kombinasi dari kelainan-kelainan lain, dan dilatasi dari atrium kiri (Gani, 2007). Hasil penelitian yang dilakukan menyebutkan bahwa yang paling sering ditemukan pada mitral stenosis, dan sering juga ditemukan di aorta insufisiensi, mitral insufiensi, aorta stenosis, kardiomiopati dilatasi, dan sistemik hipertensi adalah pembesaran atrium kiri (Gani, 2007).

Pasien yang mengalami ST elevasi akan mengalami nyeri dibagian dada yang khas yang dirasakan $>20$ menit dan gejalanya timbul persisten di segmen ST elevasi. Kondisi ini biasanya terjadi ketika adanya penyumbatan plak aterosklerosis di arteri koroner dan terjadi penyumbatan di miokardium (Marshall, 2011). Pasien yang mengalami AV block harus dilihat terlebih dahulu derajat yang dialmianya. AV block terbagi menjadi tiga derajat. Derajat 1 biasanya berkaitan dengan penyakit jantung organik yang dikarenakan oleh efek digitalis. Hal ini sering ditemukan pada klien yang mengalami infark miokard pada dinding inferior. AV Blok derajat 2 menghasilkan suatu frekuensi jantung yang menurun dan biasanya curah jantung mengalami penurunan.

AV Blok 
Dinamika Kesehatan Jurnal Kebidanan dan Keperawatan Vol 10 No. 1 Juli 2019 ( ISSN: 2086-3454 EISSN: 2549-4058)

url: http://ojs.dinamikakesehatan.unism.ac.id DOI : https://doi.org/10.33859/dksm.v10i1.462

Perbedaan Gambaran Ekg Pada Pasien Hipertensi Dengan Lama Riwayat Menderita <5 Tahun Dan $\geq 5$ Tahun

Di Poli Penyakit Dalam Rumah Sakit H. Damanhuri Barabai

Derajat 3 berkaitan penyakit jantung

organic, intoksikasi digitalis, dan

infark miokard. Penurunan drastis frekuensi

jantung menyebabkan perfusi ke organ vital

menurun, seperti otak, ginjal, jantung,

paru, dan kulit. (Aspiani, 2015). Pasien

yang mengalami RBBB inkomplit, penegakan

diagnosa RBBB inkomplit didasarkan kriteria

yang sama pada RBBB komplit yang berbeda

hanya durasi QRS kompleks yang $<0,12$ detik

(Willem, 1985).

Tabel 3. Gambaran EKG Pada Pasien Hipertensi

\begin{tabular}{|c|c|c|}
\hline Gambaran EKG & $\mathrm{f}$ & $\%$ \\
\hline Tidak Normal & 21 & 70 \\
\hline Normal & 9 & 30 \\
\hline Total & 30 & 100 \\
\hline
\end{tabular}

Tabel 3. Gambaran EKG pada pasien

hipertensi dengan lama riwayat menderita $\geq 5$

tahun di Poli Penyakit Dalam Rumah Sakit H.

Damanhuri Barabai yang tidak normal sebanyak 21 orang $(70 \%)$ dan normal sebanyak 9 orang (30\%). Pada pasien yang mengalami gambaran EKG tidak normal didapatkan 14 pasien $(62,5 \%)$ yang mengalami pembesaran ruang jantung, 2 orang mengalami ICRBBB, 1 orang mengalami ICRBBB dan AV block, 1 orang mengalami atrial fibrilasi dan PVC, 1 orang yang mengalami atrial enlargement, 1 orang yang mengalami RBBB, 1 orang mengalami OMI, ST elevasi dan PVC. Ketidaknormalan gambaran EKG pada psien yang menderita hipertensi dengan lam riwayat menderita $\geq 5$ tahun dikarenakan adanya kelainan left ventruicular hypertrophy yang dialami 9 pasien. Pasien yang mengalami left ventruicular hypertrophy 7 orang dialami oleh laki-laki dan 2 orang perempuan. Rerata usia daIam peneIitian ini adaIah 56,90 tahun.

Banyaknya ketidaknormalan yang terjadi dapat dipengaruhi oleh kebiasaan penderita hipertensi seperti kebiasaan merokok, obesitas, gaya hidup, makanan yang dikonsumsi pederita yang tidak sehat, sehingga menyebabkan banyaknya terjadi kelainan jantung pada penderita. Pada penelitian ini ditemukan sebanyak 12 orang yang mengalami kelainan jantung lebih dari satu.

Penelitian ini searah dengan penelitian Soraya, Asnar dan Aminuddin (Soraya, 2007) 
Dinamika Kesehatan Jurnal Kebidanan dan Keperawatan Vol 10 No. 1 Juli 2019 ( ISSN: 2086-3454 EISSN: 2549-4058)

url: http://ojs.dinamikakesehatan.unism.ac.id DOI : https://doi.org/10.33859/dksm.v10i1.462

Perbedaan Gambaran Ekg Pada Pasien Hipertensi Dengan Lama Riwayat Menderita <5 Tahun Dan $\geq 5$ Tahun

Di Poli Penyakit Dalam Rumah Sakit H. Damanhuri Barabai

didapatkan 2 pasien dengan hipertrofi

ventrikel kiri yang terlihat pada gambaran

EKG pasien hipertensi, dimana jenis kelamin

kedua pasien tersebut adalah laki-laki. Usia

pasien tersebut berusia 55 tahun

dan 61 tahun

dengan

gambaran hipertrofi ventrikel kiri pada

rekaman EKG. Insiden gambaran EKG

meningkat pada hipertrofi ventrikel kiri

dengan bertambahnya usia pasien, sedikit

lebih menonjol pada laki-laki dan 1 dari 10

orang dalam interval usia 30 sampai 62

tahun dicurigai memiliki hipertrofi ventrikel

kiri selama 12 tahun (Soraya, 2007). Hal

yang spesifik didapatkan dalam

Gambaran EKG pada kedua pasien

tersebut yang memperlihatkan gambaran

hipertrofi ventrikel kiri yakni jumlah

gelombang S pada lead V1 dengan

gelombang $\mathrm{R}$ pada lead V5/V6 (dipiIih

yang lebih tinggi) $>35 \mathrm{~mm}, \quad$ hal ini

sesuai dengan kualifikasi terhadap

hipertrofi ventrikel kiri (Soraya, 2007).

Tekanan darah yang meningkat secara sistemik bisa meningkatkan kekuatan terhadap pemompaan darah

dari ventrikel kiri, yang menyababkan beban kerja jantung jadi bertambah. Sebagai dampaknya terjadi hipertrofi ventrikel kiri guna meningkatkan kontraksi. Hipertrofi tersebut ditandai dengan ketebalan dinding bertambah, buruknya fungsi ruang, dan ruang jantung yang dilatasi. Namum kekuatan ventrikel dalam mempertahankan curah jantung dengan hipertrofi kompensasi akhirnya terlampaui dan menimbulkan payah jantung dan dilatasi. Jantung semakin terancam seiring dengan aterosklerosis koroner yang semakin parah. Angina pectoris juga bisa terjadi dikarenakan adanya gabungan kebutuhan oksigen miokard yang bertambah dampak dari penambahan massa miokard dan penyakit arterial koroner yang cepat (Marulam, 2006).

Kerusakan organ pada jantung karena hipertensi mencakup gagal jantung, iskemia (infark miokard), dan hipertrofi ventrikel kiri (13) Hipertensi menjadi faktor risiko terjadinya pembesaran ventrikel, abnormalitas aliran arteri coronari dan disfungsi sistolik 
Dinamika Kesehatan Jurnal Kebidanan dan Keperawatan Vol 10 No. 1 Juli 2019 ( ISSN: 2086-3454 EISSN: 2549-4058)

url: http://ojs.dinamikakesehatan.unism.ac.id DOI : https://doi.org/10.33859/dksm.v10i1.462

Perbedaan Gambaran Ekg Pada Pasien Hipertensi Dengan Lama Riwayat Menderita <5 Tahun Dan $\geq 5$ Tahun

Di Poli Penyakit Dalam Rumah Sakit H. Damanhuri Barabai

dan diastolik. Kompleks abnormalitas tersebut disebut sebagai Hipertensive Heart Disease

(HHD) yang pada akhirnya bisa terjadi gagal jantung (Sawicka, 2011).

Hipertrofi ventrikel kiri adalah kerusakan organ target yang umum. Kerusakan organ sasaran dampak dari hipertensi sebesar 31\% yang mengakibatkan Left Ventricular Hypertrophy (LVH), 10,8\% mengakibatkan gagal jantung, $8,9 \%$ mengakibatkan kerusakan serebrovaskuIar yang salah satunya adalah stroke, tetapi hasil penelitian didapatkan tidak bermakna. Tekanan darah yang tidak terkontrol dengan baik $(\geq 140 / 90 \mathrm{mmHg}$ ) adalah salah satu penyebab kerusakan organ sasaran (Ulya, 2017).

Pasien yang mengalami STEMI adalah salah satu spektrum sindroma koroner akut yang paling berat juga salah satu yang paling beresiko tinggi. Diawali dengan pasien yang membutuhkan tindakan darurat yang merupakan penentu antara hidup dan mati (Aspiani, 2015). Menurut Muttaqin (2009) ada lima faktor risiko STEMI yang dapat diubah (modifiable) yaitu merokok, hipertensi, hiperglikemia, kolesterol darah tinggi, dan pola tingkah laku (Muttaqin, 2009).

Pasien yang mengalami kelainan PVC merupakan dampak dari adanya otomatisasi sel otot ventrikel yang meningkat. PVC dapat disebabkan toksitas digitalis, hipoksia, hypokalemia, demam, asidosis, latihan. PVC jarang terjadi, biasanya klien

merasa berdebar-debar tetapi keluhan lain tidak ada. Namun demikian, perhatian harus terletak pada kontraksi premature yang dapat menyebabkan aritmia ventrikel yang lebih serius (Muttaqin, 2009).

Pasien yang mengalami kelainan atrial fibrilasi yang menggambarkan keadaan yang sering ditemui pada hipertensi. Pada pasien hipertensi dengan atrial fibrilasi harus dinilai kemungkinan terjadinya tromboemboli denga nsistim skoring yang sudah dijabarkan pada guidelines ESC dan sebagian dari pasien tersebut wajib mendapatkan terapi antikoagulan, terkecuali 
Dinamika Kesehatan Jurnal Kebidanan dan Keperawatan Vol 10 No. 1 Juli 2019 ( ISSN: 2086-3454 EISSN: 2549-4058)

url: http://ojs.dinamikakesehatan.unism.ac.id DOI : https://doi.org/10.33859/dksm.v10i1.462

Perbedaan Gambaran Ekg Pada Pasien Hipertensi Dengan Lama Riwayat Menderita <5 Tahun Dan $\geq 5$ Tahun

Di Poli Penyakit Dalam Rumah Sakit H. Damanhuri Barabai

ditemukan kontraindikasi. Sebagian besar pasien hipertensi dengan atrial fibrilasi, ternyata memiliki laju ventrikel yang cepat (Suciadi, 2016).

Pasien yang mengalami Old miocard infark terjadi karena adanya sumbatan dari plak di aliran darah kejaringan otot jantung yang sudah kronis yang menyebabkan berpengaruhnya terhadap kerja otot jantung. Infark miocard yang mengenai endokardium sampai epikardium disebut infark transmural, namun bisa juga hanya mengenai daerah subendokardial (Riliantono, 2004).

Tabel 4. Hasil Analisis Perbedaan Gambaran EKG Pada Pasien Hipertensi dengan Lama Riwayat Menderita $<5$ Tahun dan $\geq 5$ Tahun

\begin{tabular}{lcccccc}
\hline Gambaran EKG & \multicolumn{5}{c}{ Lama Riwayat Menderita } \\
& \multicolumn{5}{c}{ Hipertensi } \\
\cline { 2 - 7 } & $<5$ tahun & $\geq 5$ tahun & \multicolumn{2}{c}{ Total } \\
\cline { 2 - 7 } & $\mathrm{f}$ & $\%$ & $\mathrm{f}$ & $\%$ & $\mathrm{f}$ & $\%$ \\
\hline Tidak normal & 8 & 13, & 21 & 35 & 29 & 48, \\
\multirow{2}{*}{ Normal } & 22 & 36, & 9 & 15 & 31 & 51, \\
\multicolumn{1}{c}{ Total } & 30 & 50 & 30 & 50 & 60 & 100 \\
\hline \multicolumn{1}{c}{ Uji statistik fisher's exact test $p=0,002$} & $\alpha=0,05$ \\
\hline
\end{tabular}

Tabel 4. Hasil analisis statistik uji fisher's exact test didapatkan $p=0,002$ berarti $p<0,05$

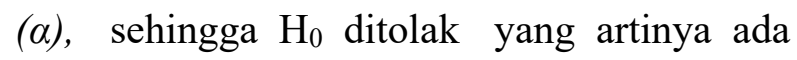
perbedaan gambaran EKG pada pasien hipertensi dengan lama riwayat menderita $<5$ tahun dan $\geq 5$ tahun di Poli Penyakit Dalam Rumah Sakit H. Damanhuri Barabai. Hal ini dikarenakan berbeda jauh gambaran EKG pada pasien dengan lama riwayat menderita $<5$ tahun dan $\geq 5$ tahun. Semakin lama pasien menderita hipertensi maka semakin berat komplikasi yang dialami pasien. Faktor yang dapat memperberat terjadinya hipertensi salah satunya adalah usia pasien dan gaya hidup penderita yang tidak sehat sehingga penderita yang sudah lama menderita hipertensi lebih banyak mengalami kelainan jantung lebih dari satu.

Penelitian menyebutkan bahwa semakin lama seseorang menderita hipertensi maka komplikasi yang timbul juga semakin berat. Pada hipertensi yang berlangsung lama, akan mengakibatkan kerusakan pada organ jantung, pembuluh darah, ginjal, dan otak (Wahyuningsih, 2018). Komplikasi yang dialami oleh penderita hipertensi terjadi akibat adanya tekanan darah yang meningkat dan berlangsung secara bekeIanjutan, sehingga berakibat pada perubahan dinding 
Dinamika Kesehatan Jurnal Kebidanan dan Keperawatan Vol 10 No. 1 Juli 2019 ( ISSN: 2086-3454 EISSN: 2549-4058) url: http://ojs.dinamikakesehatan.unism.ac.id DOI : https://doi.org/10.33859/dksm.v10i1.462

Perbedaan Gambaran Ekg Pada Pasien Hipertensi Dengan Lama Riwayat Menderita <5 Tahun Dan $\geq 5$ Tahun Di Poli Penyakit Dalam Rumah Sakit H. Damanhuri Barabai

pembuluh darah dan jantung, atau akibat terjadinya proses aterosklerosis yang diperparah dengan terjadinya hipertensi (Sawicka, 2011). Tingkat hipertensi akan terus meningkat seiring dengan bertambahnya usia penderita. Kejadian hipertensi yang terbanyak terdapat di Pulau Jawa dengan usia rerata $\geq 45$ tahun (Setiawan, 2016).

Penelitian lainnya yang sudah dilakukan insiden hipertensi pada daerah perkotaan lebih tinggi pada pedesaan dengan rerata usia $\geq 45$ tahun (Pradono, 2011). Bertambahnya usia, pembuluh darah akan menjadi lebih kaku dan elastisitas pembuluh darah menurun akan memaksa darah pada setiap denyut jantung dalam melalui lumen yang sempit dari pada biasanya (Muhammadun, 2010). Hal ini yang menmgakibatkan meningkatnya risiko hipertensi meningkat pada usia pertengahan (>40 tahun), (Sudalit, 2001).

\section{Hipertensi bisa menyebabkan dan} disebabkan oleh kerusakan di berbagai bagian organ sasaran meliputi retina, pembuluh darah, ginjal, sisitem saraf pusat, dan jantung.
Hipertensi yang berlangsung lama dan tidak terkontrol bisa mengubah struktur pembuluh darah, sistem konduksi jantung, dan miokard. Peralihan ini bisa menyebabkan terjadinya kelainan, salah satunya hipertrofi ventrikel kiri (Diamond, 2005).

\section{PENUTUP}

Gambaran EKG pada pasien hipertensi dengan lama riwayat menderita $<5$ tahun yang normal sebanyak 22 orang $(73,3 \%)$ dan tidak normal sebanyak 8 orang (26\%). Gambaran EKG pada pasien hipertensi dengan lama riwayat menderita $\geq 5$ tahun yang tidak normal sebanyak 21 orang (70\%) dan normal sebanyak 7 orang (30\%). Ada perbedaan gambaran EKG pada pasien hipertensi dengan lama riwayat menderita $<5$ tahun dan $\geq 5$ tahun.

Saran bagi rumah sakit diharapkan bisa digunakan untuk evaluasi rumah sakit terhadap pemeriksaan EKG yang dilakukan terhadap pasien hipertensi dan monitoring kepada pasien hipertensi dan juga penelitian ini bisa menjadi bahan evaluasi SPO rumah 
Dinamika Kesehatan Jurnal Kebidanan dan Keperawatan Vol 10 No. 1 Juli 2019 ( ISSN: 2086-3454 EISSN: 2549-4058)

url: http://ojs.dinamikakesehatan.unism.ac.id DOI : https://doi.org/10.33859/dksm.v10i1.462

Perbedaan Gambaran Ekg Pada Pasien Hipertensi Dengan Lama Riwayat Menderita <5 Tahun Dan $\geq 5$ Tahun

Di Poli Penyakit Dalam Rumah Sakit H. Damanhuri Barabai

sakit tentang pemeriksaan EKG, khususnya di poli penyakit dalam yang belum ada SPO tentang pemeriksaan EKG yang sangat diperlukan pembentukan SPO yang sesuai.

\section{DAFTAR PUSTAKA}

World Health Organization (WHO). A Global Brief On Hypertension; Silent Killer, Global Public Health Crisis. Geneva: WHO; 2013.

Available from: URL: http://www.who.int, diakses tanggal 20 Maret 2018.

Kementerian Kesehatan Republik Indonesia. Hipertensi The Silent Killer, Pusat Data dan Informasi. 2015. Available from: URL: http://www.depkes.go.id, diakses tanggal 15 April 2018.

Kementrian

Kesehatan Republik Indonesia. Hipertensi, Pusat Data dan Informasi Kementrian Kesehatan RI. 2014. Available from: URL: http://infodatin.hipertensiml.go.id, 23 Maret 2018.

Riset Kesehatan Dasar(Riskesdas).

Laporan hasil riset kesehatan dasar 2013, Jakarta; 2014. Available from: URL: http://www.depkes.go.id, diakses pada 8 Maret 2018.

Sawicka et. al. Hypertension-The Silent Killer, Journal of PreClinical and Clinical Research 2011; 5 (2).

Soraya, F., Asnar STP, E \& Aminuddin, M. Profil EKG Pasien Hipertensi di Poliklinik Jantung, Jurnal Ners 2016; 11 (1).

Gani, A. Kriteria Pembesaran Atrium Kiri Secara Elektrokardiografi, Majalah Kedokteran Nusantara 2007; 40 (1).
Marshall K. Acute Coronary Syndrome: diagnosis, risk assessment and management, Nursing Standard 2011; 25, pp 47-57.

Aspiani, YR. Buku Ajar Asuhan Keperawatan Klien Gangguan Kardiovaskular. Jakarta: EGC; 2015.

Hindman MC, Wagner GS, JaRo M, Atkins JM, Scheinman MM, DeSanctis RW,Hutter AH Jr, Yeatman L, Rubenfire M, Pujura C, Rubin M, Morris JJ. The clinical significance of bundle branch block complicating acute myocardial infarction. Clinical characteristics, hospital mortality, and oneyear follow-up. Circulation 1978; 58, pp 679-688.

Willems JL, Robles de Medina EO, Bernard R, et al. Criteria for intraventricular conduction disturbances and pre-exitation: World Heart organization/ International Society and Federation for Cardiology Task Force. J Am Coll Cardiol. 1985;5, pp 1261-1275.

Marulam, MP. Penyakit Jantung Hipertensi; Buku Ajar Ilmu Penyakit Dalam Jilid III Edisi Keempat. Jakarta: Balai Penerbit Fakultas Kedokteran Universitas Indonesia; 2006.

Yogiantoro, M. Hipertensi Esensial. Jakarta: EGC; 2006.

Ayodele, OE., Alebiosu, CO, Salako BL, Awodein, OG., \& Adigun,AD. Target organ damage and associated clinical conditions among Nigerians with treated hypertension, Cardiovascular Journal Of South Africa 2005; 16 (2): 89-93.

Ulya, Z., Iskandar, A., Asih, FT. Pengaruh Pendidikan Kesehatan dengan Media Poster terhadap Pengetahuan Manajemen Hipertensi 
Dinamika Kesehatan Jurnal Kebidanan dan Keperawatan Vol 10 No. 1 Juli 2019 ( ISSN: 2086-3454 EISSN: 2549-4058) url: http://ojs.dinamikakesehatan.unism.ac.id DOI : https://doi.org/10.33859/dksm.v10i1.462

Perbedaan Gambaran Ekg Pada Pasien Hipertensi Dengan Lama Riwayat Menderita <5 Tahun Dan $\geq 5$ Tahun Di Poli Penyakit Dalam Rumah Sakit H. Damanhuri Barabai

pada Penderita Hipertensi, Jurnal Keperawatan Soedirman 2017; 12 (1).

Muttaqin, A. Pengantar Asuham Keperawatan Klien dengan Gangguan Sistem Kardiovaskuler. Jakarta: Salemba Medika; 2009.

Suciadi, LP. Memahami Pemeriksaan Jantung. Jakarta: EGC; 2016.

Rilantono, LI. Buku Ajar Kardiologi. Jakarta: Gaya Baru; 2004.

Goldberger AL. Ventricular conduction distrubances : bundle branch block, disunting dalam: clinical electrocardiography a simplified approach, edisi ke tujuh. Mosby Elsevier; 1998.

Wahyuningsih, S., Amalia, M \& Bustamam, N. Pengaruh Derajat Hipertensi, Lama Hipertensi dan

Hiperlipidemia dengan Gangguan

Jantung dan Ginjal Pasien Hipertensi di Posbindu Cisalak Pasar. Jurnal Kesmas Indonesia 2018; 10 (1).

Setiawan, $\quad$ Z. Prevalensi dan determinan hipertensi di Pulau Jawa tahun 2004. Kesmas: Jurnal Kesehatan Masyarakat Nasional 2006; 1 (2)

Pradono, J. Faktor-faktor yang memengaruhi terjadinya hipertensi di daerah perkotaan (analisis data riskesdas 2007). Gizi Indonesia 2010; 33 (1), pp 59-66.

Muhammadun, AS. Hidup bersama hipertensi. Jakarta: iN-Books; 2010.

Susalit, E. Hipertensi primer dalam: Buku. Ajar Ilmu Penyakit Dalam. Ed. 3 Vol. $3 . \quad$ Jakarta: Balai Penerbit FK-UI; 2001.

Krummel, DA. Medical nutrition therapy in hypertension, dalam:
Mahan, L. K. dan Escott-Stump (eds). 200. USA: Saunders Co; 2004.

Diamond, JA. \& Phillips, RA. Hypertensive Heart Disease. Hypertens Res 2005; 28 (3). 